Original Research Paper

\title{
Supplementation of Prill Fat Derived from Palm Oil on Nutrient Digestibility and Dairy Cow Performance
}

\author{
${ }^{1}$ Lolita Udin Riestanti, ${ }^{2}$ Despal and ${ }^{2}$ Yuli Retnani \\ ${ }^{1}$ Study Program Nutrition and Feed Technology, Department of Nutrition and Feed Technology, Faculty of Animal Science, \\ IPB University (Bogor Agricultural University), Jl. Agatis, Kampus IPB Dramaga, Bogor, 16680, West Java, Indonesia \\ ${ }^{2}$ Department of Nutrition and Feed Technology, Faculty of Animal Science, IPB University, \\ (Bogor Agricultural University), Jl. Agatis, Kampus IPB Dramaga, Bogor, 16680, West Java, Indonesia
}

Article history

Received: 08-02-2021

Revised: 29-05-2021

Accepted: 31-05-2021

Corresponding Author:

Yuli Retnani

Department of Nutrition and Feed Technology, Faculty of Animal Science, IPB University,(Bogor Agricultural University), Jl. Agatis, Kampus IPB Dramaga, Bogor, 16680, West Java, Indonesia

Email: yuli.retnani@yahoo.com
Abstract: Prill fat is a hydrogenated vegetable oil which contains more than $85 \%$ palmitic acid with a high melting point. Due to this reason, it does not melt at rumen temperature and bypass rumen degradation. This study was aimed to determine the optimum level of prill fat (86\% palmitic acid) supplementation in dairy ration on fermentation characteristics, feed digestibility, milk production, milk components and milk fatty acid profiles. In vitro analysis used Randomized Block Design with 4 treatments and 4 replications and the in vivo analysis using $\mathrm{T}$-Test. The in vitro result showed prill fat supplementation was significantly affected the total Volatile Fatty Acids (VFA) concentration $(p<0.05)$. The addition of prill fat significantly decreased dry matter and organic matter digestibility $(p<0.01)$, Neutral Detergent Fiber (NDF) and Acid Detergent Fiber (ADF) digestibility $(p<0.05)$, total protozoa biomass $(p<0.01)$ and population of cellulolytic bacteria $(p<0.05)$. Furthermore, supplementation of prill fat in the level of $2 \%$ had no effect on $\mathrm{pH}$, ammonia $\left(\mathrm{NH}_{3}\right) \mathrm{N}$ concentration and total rumen bacteria activity. The prill fat treatment at the level of $2 \%$ had no effect on dry matter intake, milk component and milk yield on in vivo analysis. In addition, milk yield, milk component and milk fatty acids were elevated after the prill fat treatment. This research concluded, the optimum level of prill fat addition in dairy ration was at the level of $2 \%$. Supplementation of prill fat had no effect on rumen fermentation and fiber digestibility. Prill fat supplementation can be used to augment the milk yield, milk component, fatty acid composition in milk and had no effect on Atherogenicity Index (AI) and Hypocholesterolemic/Hypercholesterolemic (HH).

Keywords: Milk, Fatty Acid, Palmitic Acid, Rumen Fermentation

\section{Introduction}

Dairy cow production is likely to be adversely affected by feed nutrients and adequate nutrient requirements. The insufficiency of feed availability and quality for its production cause low productivity of dairy cows (Hasanah et al., 2017). Dairy cows in Indonesia mostly fed with Napier grass and concentrate which produced by cooperative (Zahera and Permana, 2015). Napier grass is a productive forage (250 ton/ha/year) (Despal et al., 2019) but it has a low quality (55\% Total Digestible Nutrient(TDN), 8$12 \%$ Crude Protein (CP)) (Riestanti et al., 2020) and is influenced by seasons (Sajimin and Purwantari, 2019). To fulfil the requirement of dairy cattle average production (13.5 $\mathrm{L} /$ head/day) that require $60.9 \% \mathrm{TDN}$ and $12.20 \% \mathrm{CP}$ (NRC, 2001), dairy farmers often added concentrate. Concentrate that used by a traditional dairy farmer contained $<60 \%$ TDN. Lack of nutrient fulfilment has become bigger during the dry season when forage quality rapidly decreased (Retnani et al., 2014) as an increased of livestock requirement which driven by the higher maintenance requirement of dairy cattle (Sutarno and Setyawan, 2016). Supplementation with the other energy sources should be considered to fulfil the lack of energy in dairy ration.

Fat can be used as an alternative for low energy ration supplementation (Riestanti et al., 2020). Fat supplementation in dairy ration can be used as a high energy density source for ruminants with a low heat increment (Santos et al., 2017). Fat can be used as a post-rumen energy source which could overcome the low quality of forages and increase milk production (Naik, 2013). However, in fat supplementation, level and techniques should be considered to avoid rumen metabolic disturbance. The addition of fat in dairy rations often causes termination in the rumen fermentation due to the nature of fat that surrounds protozoa (Firkins et al., 2007), so that protozoa immobilization will be agitated. The problems 
occur mainly due to the high utilization level of fat in form of oil (more than 6-7\% total fat in ration) (NRC, 2001).

The technique of fat supplementation was aimed at protecting fat (rumen bypass). Ca-soap, hydrogenated partially process, formaldehyde, are among the popular bypass fat protection technique. Currently, prill fat has become popular that used for temperate dairy cattle especially, during the summer season to increase energy ration and decrease heat increment.

Prill fat is a hydrogenated vegetable oil which contain more than $85 \%$ palmitic fatty acid with high melting point. Due to this reason, prill fat does not melt at rumen temperature and bypass rumen degradation so that these fatty acids are absorbed directly in the small intestine and digested in small intestine by lipase enzyme (Kundu et al., 2014).

Prill fat supplementation was reported to increase energy consumption and known to have a significant effect on increasing milk production. It has been found that hydrogenated palm oil provides a better energy supply for lactating dairy cows than calcium soap of palm oil fatty acid (Karcagi et al., 2010). Prill fat is more effective to work as a source of energy to maintain the energy balance in lactating ruminants during the summer conditions (Somagond et al., 2020). Accordingly, many studies have been conducted with the aim of fat as an energy source using prill fat high in palmitic fatty acid was reported by Kundu et al. (2014), de Souza et al. (2017) and Mathews et al. (2016), which stated that there was an increase in milk production and milk fat in dairy cow, but had no effect on body weight gain and dry matter intake of dairy cows.

Utilizations of prill fat in Indonesia are still limited. Our previous research showedthatutilization of $2 \%$ prill fat contained $95 \%$ palmitic acid improved the total VFA concentration without interfering the rumen fermentation and digestibility (Riestanti et al.,2020). Study on utilization of $2 \%$ prill fat in dairy ration with different palmitic acid content showed that prill fat with $86 \%$ palmitic acid has improved milk production and quality. So far, there is no information on the optimum level of $86 \%$ palmitic acid prill fat supplementation in the dairy ration.

Therefore, this study was aimed to determine the optimum level of prill fat $(86 \%$ palmitic acid) supplementation in dairy ration on fermentation characteristics, feed digestibility, milk production, milk components and milk fatty acid profiles.

\section{Materials and Methods}

\section{Ration Preparation}

The study was conducted from February 2020 to August 2020 at the Laboratory of Dairy Nutrition, IPB University and KUNAK, Cibungbulang, Dairy Farm. Dairy cows ration was constructed using elephant grass, concentrate and soybean curd with $58.28 \%: 33.62 \%: 8.10 \%$ ratio of DM. The ratio of feed was made based on the provision which made at KUNAK dairy farm, Cibungbulang, Bogor.
Table 1 showed the composition and nutrient content of feed ingredients for dairy cow.

The dietary nutrient requirement and the maintenance needs of the dairy cows were calculated in accordance with NRC (2001), where the needs of dairy cow with an average body weight of $417 \mathrm{~kg}$ and the $12 \mathrm{~L}$ of milk production need of $12.20 \%$ crude protein and $61.30 \%$ TDN. Based on the calculations, crude protein and TDN were not fulfilled if we provided with the local feed only. Supplementing with prill fat is expected to improve the energy. Prill fat is needed to fulfill the energy of the dairy cow which has a low energy in their ration. The ration composition and prill fat composition of palm oil byproduct was presented in Table 2 and 3. respectively.

\section{In Vitro Trial}

In vitro analysis in this study was carried out following Tilley and Terry (1963) method. The rumen fluid was drawn from two fistulated dairy cows for in vitro analysis, following standard laboratory procedures. Sample of the ration $(0.5 \mathrm{~g})$ and McDougall solution $(40 \mathrm{~mL})$ for each treatment was poured into fermenter tubes. Then, the rumen fluid from different cows (10 $\mathrm{mL}$ ) added to the tube followed by the addition of $\mathrm{CO} 2$ (anaerobic condition). Dry Matter Digestibility (DMD) and Organic Matter Digestibility (OMD) measurements were conducted by incubating the fermenter tubes filled with the sample of ration at $39^{\circ} \mathrm{C}$ for $48 \mathrm{~h}$ in the shaker water bath. $\mathrm{pH}$, ammonia $(\mathrm{NH} 3) \mathrm{N}$ concentration and total VFA were carried out in $4 \mathrm{~h}$ after the incubation.

Research variables observed consisted of fermentation characteristics ( $\mathrm{pH}$, microbe's activity, ammonia $\left(\mathrm{NH}_{3}\right) \mathrm{N}$ concentration and total VFA production), nutrient digestibility (dry matter and organic matter), NDF and ADF digestibility.

\section{Collection and Measurement Samples of In Vitro Analysis}

Characteristics of rumen fermentation observed in this study were the concentration of ammonia which analyzed through Conway micro diffusion method (Conway, 1962), pH (analyzed by pH meter) and steam distillation method used to analyze the total VFA concentration. Measurement of the total population of protozoa and bacterial was carried out using the Ogimoto and Imai (1981) method. Nutrient digestibility (dry matter digestibility and organic matter digestibility were measured after $48 \mathrm{~h}$ of incubation. The 2 drops of $\mathrm{HgCl}_{2}$ were added to the substrate after $48 \mathrm{~h}$ incubation period (to stop microbe's activity), then it was centrifuged at $3000 \mathrm{rpm}$ in $15 \mathrm{~min}$ ato separate the supernatant and solid component. Supernatants were eliminating and $50 \mathrm{~mL}$ of pepsin solution were added to the solid component in each tube. Tubes were incubated in the shaker water bath at $39^{\circ} \mathrm{C}$ for $48 \mathrm{~h}$. Then, supernatants were eliminated and the solids were washed with hot water and filtered using vacuum pump and Whatman filter paper. Substrate placed in the porcelain cup and dried at the oven 
$\left(105^{\circ} \mathrm{C}\right.$ in $\left.24 \mathrm{~h}\right)$ for dry matter measurements. Then, substrates were incinerated in the furnace at $6 \mathrm{~h}\left(600^{\circ} \mathrm{C}\right)$ for the organic matter measurements.

Neutral Detergent Fiber Digestibility (NDFD) and Acid Detergent Fiber Digestibility (ADFD)

The residue from in vitro was analyzed according to the method described by Van Soest et al. (1991) using ANKOM 200 fiber analyzer. The in vitro residue was put into F57 fiber bag and then heated to a temperature of $100^{\circ} \mathrm{C}$ in neutral detergent solution for $75 \mathrm{~min}$ and acid detergent solution for $60 \mathrm{~min}$ to get the residual weight after the extraction process. $\mathrm{NDF}$ and $\mathrm{ADF}$ values are calculated from the residual weight after extraction divided by the initial sample weight.

\section{In Vivo Trial}

The study was conducted for 49 days, located in KUNAK, Cibungbulang dairy farm. A total of 20 multiparous Holstein cows in early and mid-lactation were managed under the intensive condition and adjusted to the breeder preference, researchers only added feed supplements in the morning. The feed consumption calculated every day. The forage and concentrate used are weighed using a hanging scale with a of $100 \mathrm{~kg}$ capacity. Milking is done 2 times a day, at $06.30-08.00 \mathrm{WIB}$ in the morning and at 15.30-17.00 WIB in the afternoon. The milk production is measured using a $3000 \mathrm{~mL}$ measuring cup. Dairy cow milk production is collected in the morning and afternoon during milking. Analysis of the quality of milk is carried out using Lactoscan.

\section{Analysis of the Fatty Acid Milk Profile}

The milk fatty acid profile was analyzed on the last day of observation using Near-Infared Spectroscopy (NIRS),
Animal Logistic Indonesia Netherland (ALIN) Laboratory. Milk samples were put into a petri dish, then placed on a device for further spectrum analysis using NIRS.

\section{Research Design and Data Analysis}

\section{In Vitro Trial}

The experimental diets of in vitro were arranged using Randomized Block Design with 4 treatments and 4 replications, as follows:

$\mathrm{P}_{1}=$ Control ration in the form of elephant grass $58.28+33.62 \%$ soybean curd $+8.10 \%$ concentrate

$\mathrm{P}_{2}=\mathrm{P} 1+2 \%$ palm oil prill fat

$\mathrm{P}_{3}=\mathrm{P} 1+4 \%$ palm oil prill fat

$\mathrm{P}_{4}=\mathrm{P} 1+6 \%$ palm oil prill fat

\section{In Vivo Trial}

The in vivo trials were designed by T-Test using the SASUniversity edition. This study was carried out with 2 treatments and 5 replications with each treatment consisting of 2 lactating dairy cows, as follows:

$\mathrm{T} 0=$ Control ration in the form of forage + concentrate + soybean curd

$\mathrm{T} 1=\mathrm{T} 0+2 \%$ palm oil prill fat (optimum results in in vitro tests)

The data were analyzed using ANOVA and the significant different among treatments were further tested by Duncan multiple range test using the SAS University edition. Differences among treatments were considered significant at $p<0.01$ and $p<0.05$.

Table 1: Composition and nutrient content of feed ingredients for Holstein cows

\begin{tabular}{|c|c|c|c|c|c|c|c|}
\hline \multirow[t]{2}{*}{ Feedstuffs } & \multicolumn{7}{|c|}{ Nutrient content (\%) } \\
\hline & Dry matter & Ash & Crude protein & Ether extract & Crude fiber & $\mathrm{NFE}^{\mathrm{b}}$ & $\mathrm{TDN}^{\mathrm{b}}$ \\
\hline$\overline{\text { Elephant grass }^{\mathrm{a}}}$ & 24.94 & 11.80 & 9.05 & 2.13 & 31.75 & 45.27 & 51.459 \\
\hline Concentrate $^{\mathrm{a}}$ & 93.62 & 7.46 & 15.60 & 3.60 & 8.41 & 64.93 & 65.212 \\
\hline Soybean curd ${ }^{\mathrm{a}}$ & 13.60 & 7.36 & 18.67 & 1.15 & 14.10 & 58.72 & 64.901 \\
\hline
\end{tabular}

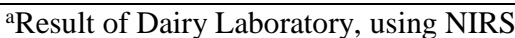

${ }^{b}$ Nitrogen free extract (NFE)

${ }^{\mathrm{b}}$ Total digestible nutrient $(\mathrm{TDN})=-14.8356+1.3310(\% \mathrm{CP}$ : Crude Protein $)+0.7923(\%$ NFE: Nitrogen Free Extract $)+0.9787(\% \mathrm{EE}$ : Ether Extract) + 0.5133(\%CF: Crude Fiber) (Wardeh, 1981)

Table 2: Composition and nutrient content of dairy ration for Holstein cows

\begin{tabular}{lr}
\hline Item & Percentage $(\%$ DM $)$ \\
\hline Composition & 58.280 \\
Elephant grass & 33.620 \\
Soybean curd & 8.100 \\
Concentrate & 57.170 \\
Nutrient Content & 12.030 \\
Total digestible nutrient & 2.540 \\
Crude protein & 22.470 \\
Ether extract & 0.667 \\
Crude fiber & 0.481 \\
Calcium & \\
Phosphorus & \\
\hline
\end{tabular}


Table 3: Prill fat composition of palm oil by-product

\begin{tabular}{lc}
\hline Analysis & Content \\
\hline Iodine Value $(\mathrm{g} \mathrm{I} / 100 \mathrm{~g})$ & 10.03 \\
Free Fatty Acid $(\%$ as Palmitic) & 32.89 \\
Acid Value $(\mathrm{mg} \mathrm{KOH} / \mathrm{g})$ & 65.78 \\
Slip Melting Point $\left({ }^{\circ} \mathrm{C}\right)$ & 59.40 \\
Fatty Acid Composition $(\%)$ & \\
C16:0 & 86.24 \\
$\mathrm{C} 16: 1$ & 0.17 \\
$\mathrm{C} 18: 0$ & 3.49 \\
$\mathrm{C} 18: 1 \mathrm{cis}$ & 7.52 \\
$\mathrm{C} 18: 2 \mathrm{cis}$ & 1.59 \\
$\mathrm{C} 18: 3 \mathrm{cis}$ & 0.03 \\
\hline
\end{tabular}

Gas chromatography analysis

\section{Results}

Characteristics of Ruminal Fermentation and Rumen Microbial Activity (In Vitro Trial)

Prill fat supplementation had no effect on $\mathrm{pH}$, ammonia concentration, and total rumen bacteria. However, there was a significant effect of prill fat supplementation on total Volatile Fatty Acid (VFA) concentration $(\mathrm{p}<0.01)$ along with the high level of prill fat addition in the ration. The addition of prill fat at different levels had a significant effect $(\mathrm{p}<0.05)$ on the digestibility of Dry Matter (DM), organic matter (OM), Neutral Detergent Fiber Digestibility (NDFD), Acid Detergent Fiber Digestibility (ADFD), Hemicellulose Digestibility (HSD), and cellulolytic bacteria population. The fermentation characteristics of the ration supplemented with prill fat showed in Table 4 and the effects of prill fat supplementation on nutrient digestibility values showed in the Table 5 .

Based on the results of the polynomial test, the optimum level of prill fat supplementation of palm oil by-product in dairy cattle rations was $2 \%$ with a linear equation. This value indicates that the optimum level of prill fat addition did not impair the ruminal fermentability. Regression equation were used to examine the effect of prill fat addition on the ruminal fermentability. The regression equation of prill fat addition on the fermentability characteristics were shown in Fig. 1 to 3 respectively. The resulting prediction were shown below.

The protozoa prediction equation:

$\mathrm{Y}=6.5969-0.0337(\mathrm{x}),(\mathrm{Y}$ was the protozoa value and $\mathrm{x}$ was the prill fat level).

The total bacteria prediction equation:

$\mathrm{Y}=9.983-0.0422(\mathrm{x}),(\mathrm{Y}$ was the total bacteria value and $\mathrm{x}$ was the prill fat level)

The cellulolytic bacteria prediction equation:

$\mathrm{Y}=9.783+0.004(\mathrm{x})$, $(\mathrm{Y}$ was the cellulolytic bacteria value and $\mathrm{x}$ was the prill fat level)
The amylolytic bacteria prediction equation:

$\mathrm{Y}=9.7403-0.0936(\mathrm{x})$, ( $\mathrm{Y}$ was the amylolytic bacteria value and $\mathrm{x}$ was the prill fat level)

The proteolytic bacteria prediction equation:

$\mathrm{Y}=9.0955-0.0604(\mathrm{x})$, ( $\mathrm{Y}$ was the proteolytic bacteria value and $\mathrm{x}$ was the prill fat level)

The Volatile Fatty Acid (VFA) prediction equation: $\mathrm{Y}=105.62-3.0246(\mathrm{x})$, ( $\mathrm{Y}$ was the VFA value and $\mathrm{x}$ was the prill fat level)

The $\mathrm{NH}_{3}$ (ammonia) prediction equation:

$\mathrm{Y}=9.8211-0.2403(\mathrm{x})\left(\mathrm{Y}\right.$ is the $\mathrm{NH}_{3}-\mathrm{N}$ value and $\mathrm{x}$ was the prill fat level)

Similar with the rumen fermentability, the results of the polynomial test showed that the optimum level of prill fat supplementation of palm oil by-product in dairy cattle rations was $2 \%$ with a linear equation. Regression equation of prill fat addition on the Dry Matter Digestibility (DMD) and Organic Matter Digestibility (OMD) were shown in Fig. 4. The resulting prediction were shown below.

The Dry Matter Digestibility (DMD) prediction equation: $\mathrm{Y}=63.495-0.897(\mathrm{x})$, ( $\mathrm{Y}$ was the DMD value and $\mathrm{x}$ was the prill fat level)

The Organic Matter Digestibility (OMD) prediction equation:

$\mathrm{Y}=63.746-0.916(\mathrm{x})(\mathrm{Y}$ is the OMD value and $\mathrm{x}$ was the prill level fat)

\section{In Vivo Trial}

\section{Dry Matter Intake}

Feed intake is a description of the amount of feed that can be consumed by cattle for maintenance and production (NRC, 2001). The results showed that dairy cows consumed $16 \mathrm{~kg}$ of DM head/day. There was no significant effect of prill fat addition in dairy ration. However, milk yield of dairy cows was affected by the addition of prill fat in the ration $(p<0.05)$. Table 6 showed the dry matter intake of dairy cows in KUNAK, Cibungbulang.

\section{Dairy Cow's Milk Yield}

The supplementation of $2 \%$ prill fat in the ration between delta $(\Delta)$ showed significant effect $(p<0.05)$ on the enhancement of milk production. This study showed that a decrease of milk yield in control (T0) was from 12.10 to $10.75 \mathrm{~L}$ during the trial period. However, there was an enhancement of milk yield in $\mathrm{T} 2$ treatment, from 8.90 to $10.45 \mathrm{~L}$. The milk yield of dairy cows in KUNAK, Cibungbulang shown in Table 7. 


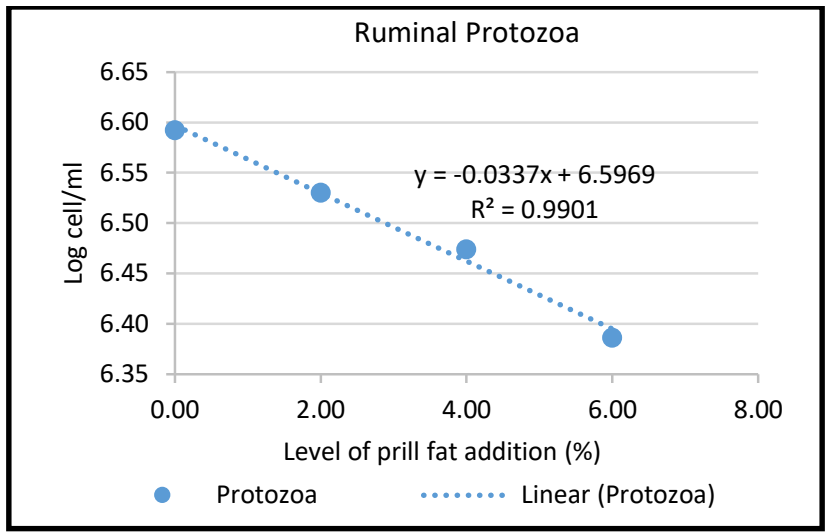

Fig. 1: The effect of prill fat addition on ruminal protozoa

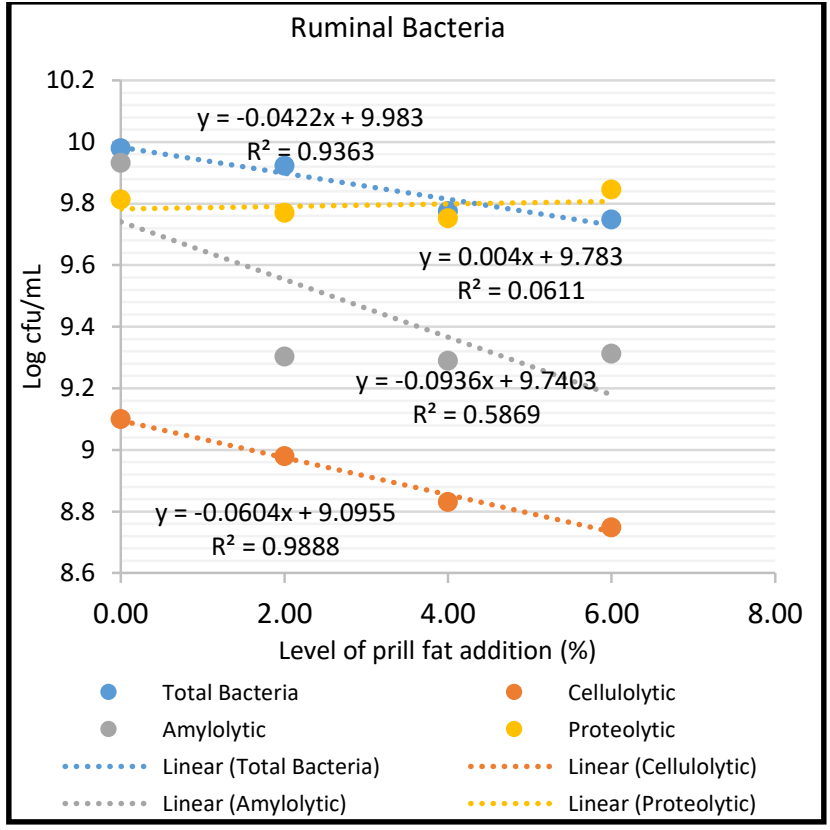

Fig. 2: Effects of prill fat addition on ruminal bacteria

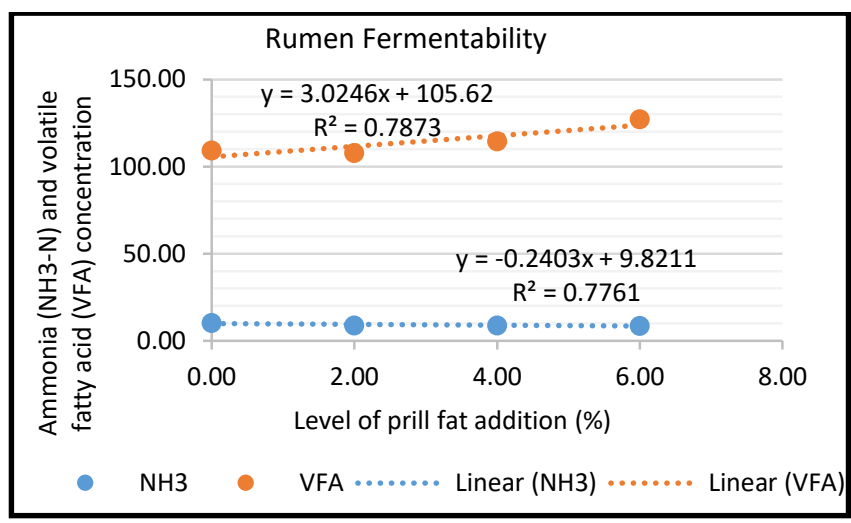

Fig. 3: Effects of prill fat addition on rumen fermentability 


\section{Dairy Cow's Milk Components}

The addition of prill fat in the ration during maintenance between delta $(\Delta)$ did affect $(p<0.05)$ the milk fat component. Supplementation of $2 \%$ prill fat had no effect on the other milk component (solid non fat, lactose, protein and total solid). The milk components in KUNAK before prill fat supplementation did not fulfill the National StandardsOrganization (BSN, 2011), especially in the fat component and total solid. Table 8 showed the milk component of dairy cows in KUNAK, Cibungbulang during the supplementation.

\section{Dairy Cow's Milk Fatty Acid Profile}

The addition of prill fat in the rations affected $(p<0.05)$ three types of milk fatty acids from 19 fatty acids analyzed using NIRS. The result shows that caproic acid, palmitoleate and conjugated linoleic acid (CLA) are fatty acids that have significant results on the effect of prill fat addition in dairy cow rations $(p<0.05)$. Table 9 . showed the result of the milk fatty acids profile supplemented with prill fat in dairy cow ration.

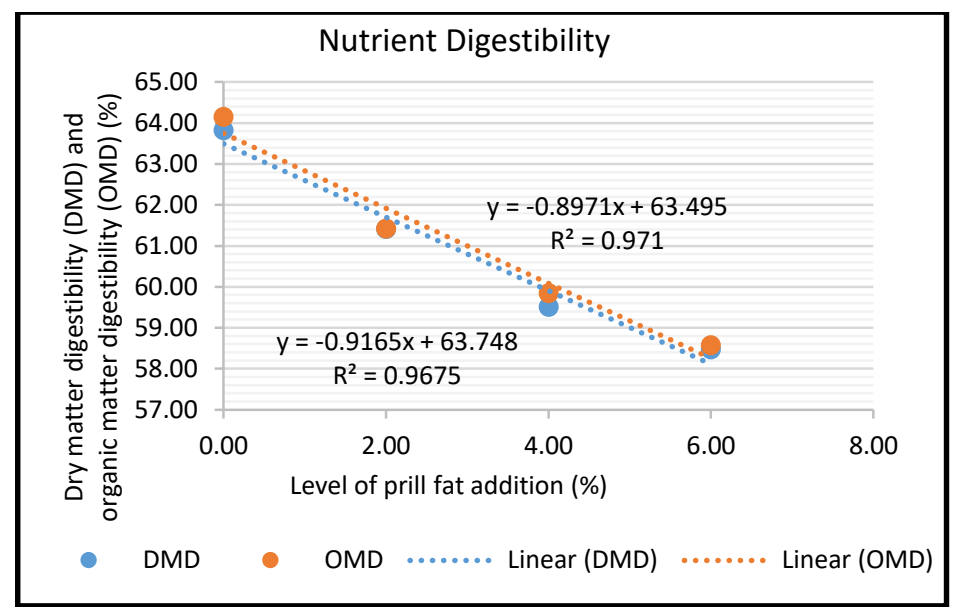

Fig. 4: Effects of prill fat addition on nutrient digestibility

Table 4: Effect of prill fat supplementation on in vitro fermentation products

\begin{tabular}{|c|c|c|c|c|c|}
\hline \multirow[b]{2}{*}{ Variables } & \multicolumn{5}{|l|}{ Treatments } \\
\hline & $\mathrm{P} 1$ & $\mathrm{P} 2$ & P3 & $\mathrm{P} 4$ & $p$ \\
\hline$\overline{\mathrm{pH}}$ & $6.86 \pm 0.11$ & $6.88 \pm 0.10$ & $6.88 \pm 0.17$ & $6.93 \pm 0.16$ & 0.312 \\
\hline $\mathrm{NH}_{3}-\mathrm{N}(\mathrm{mM})$ & $10.14 \pm 0.99$ & $8.89 \pm 0.71$ & $8.81 \pm 0.75$ & $8.56 \pm 1.54$ & 0.123 \\
\hline Total VFA (mM) & $109.25 \pm 3.00^{\mathrm{a}}$ & $107.78 \pm 10.54^{\mathrm{a}}$ & $114.59 \pm 8.17^{\mathrm{a}}$ & $127.14 \pm 7.64^{\mathrm{b}}$ & 0.007 \\
\hline Total protozoa (log cell/mL) & $6.59 \pm 0.12^{\mathrm{a}}$ & $6.53 \pm 0.12^{\mathrm{ab}}$ & $6.47 \pm 0.10^{\mathrm{b}}$ & $6.39 \pm 0.12^{\mathrm{c}}$ & 0.001 \\
\hline Total bacteria $(\log \mathrm{cfu} / \mathrm{mL})$ & $9.98 \pm 0.05$ & $9.92 \pm 0.19$ & $9.78 \pm 0.08$ & $9.75 \pm 0.11$ & 0.081 \\
\hline Cellulolytic bacteria $(\log \mathrm{cfu} / \mathrm{mL})$ & $9.10 \pm 0.97^{\mathrm{a}}$ & $8.98 \pm 1.10^{\mathrm{ab}}$ & $8.83 \pm 1.04^{\mathrm{bc}}$ & $8.75 \pm 1.07^{\mathrm{c}}$ & 0.014 \\
\hline Amylolytic bacteria (log cfu/mL) & $9.93 \pm 0.19$ & $9.30 \pm 0.82$ & $9.29 \pm 0.81$ & $9.31 \pm 0.77$ & 0.151 \\
\hline Proteolytic bacteria $(\log \mathrm{cfu} / \mathrm{mL})$ & $9.81 \pm 0.12$ & $9.77 \pm 0.07$ & $9.75 \pm 0.09$ & $9.85 \pm 0.11$ & 0.516 \\
\hline
\end{tabular}

Table 5: Effect of prill fat supplementation on nutrient digestibility values

\begin{tabular}{|c|c|c|c|c|c|}
\hline \multirow[b]{2}{*}{ Variables $(\%)$} & \multicolumn{5}{|l|}{ Treatments } \\
\hline & $\mathrm{P} 1$ & $\mathrm{P} 2$ & $\mathrm{P} 3$ & $\mathrm{P} 4$ & $p$ \\
\hline$\overline{\mathrm{DMD}}$ & $63.82 \pm 2.10^{\mathrm{a}}$ & $61.41 \pm 1.90^{\mathrm{b}}$ & $59.51 \pm 1.66^{\mathrm{bc}}$ & $58.47 \pm 1.60^{c}$ & 0.002 \\
\hline OMD & $64.15 \pm 2.23^{a}$ & $61.43 \pm 1.75^{\mathrm{ab}}$ & $59.84 \pm 1.78^{b}$ & $58.57 \pm 2.17^{b}$ & 0.008 \\
\hline NDFD & $59.03 \pm 2.27^{\mathrm{a}}$ & $55.10 \pm 3.28^{\mathrm{ab}}$ & $53.55 \pm 3.90^{\mathrm{b}}$ & $51.00 \pm 2.75^{b}$ & 0.010 \\
\hline ADFD & $45.71 \pm 2.75^{a}$ & $39.55 \pm 5.16^{\mathrm{b}}$ & $39.06 \pm 3.67^{b}$ & $37.08 \pm 2.34^{b}$ & 0.032 \\
\hline HSD & $70.24 \pm 2.60^{\mathrm{a}}$ & $68.18 \pm 5.02^{\mathrm{ab}}$ & $65.75 \pm 5.72^{\mathrm{bc}}$ & $62.71 \pm 3.42^{\mathrm{c}}$ & 0.014 \\
\hline
\end{tabular}

P1 = Control rations (58.28\%: 8.10\%: 33.62\% DM, TDN 57.17\%, CP 12.03\%), P2 = P1 + 2\% prill fat, P3 = P1+4\% prill fat, P4 = P1 $+6 \%$ prill fat; $\mathrm{DMD}=$ Dry Matter Digestibility; OMD = Organic Matter Digestibility; NDFD = Neutral Detergent Fiber Digestibility; ADFD = Acid Detergent Fiber Digestibility, HSD = Hemicellulose Digestibility

a, b, cDifferent superscripts in the same row with various letters show significant differences $(p<0.05)$ 
Lolita Udin Riestanti et al. / American Journal of Animal and Veterinary Sciences 2021, 16 (2): 172.184 DOI: 10.3844/ajavsp.2021.172.184

Table 6: Effect of prill fat supplementation on Dry Matter (DM) intake of dairy cows in KUNAK, Cibungbulang ( $\mathrm{n}=20$ )

\begin{tabular}{lllll} 
& & Dry matter intake $(\mathrm{kg})$ & & \\
Treatments & $\mathrm{n}$ & Forage & Concentrate & Soybean Curd \\
\hline T0 & 10 & $7.75 \pm 1.97$ & $4.51 \pm 1.63$ & $3.80 \pm 1.84$ \\
T1 & 10 & $7.70 \pm 1.98$ & $4.51 \pm 1.64$ & $3.80 \pm 1.85$ \\
T-Test & & 0.977 & 0.997 & 0.997 \\
\hline
\end{tabular}

$\mathrm{T} 0=$ control (without prill fat addition); $\mathrm{T} 1=$ addition of $2 \%$ prill fat in the ration

Table 7: Effect of prill fat supplementation on milk yield (L) from dairy cows in KUNAK, Cibungbulang $(\mathrm{n}=20)$

$\frac{\text { Table 7: Effect of prill fat supplementation on milk yield (L) from dai }}{\text { Milk yield (L) }}$

\begin{tabular}{lllll} 
Treatments & $\mathrm{n}$ & Before & After & Delta $(\Delta)$ \\
\hline T0 & 10 & $12.10 \pm 4.61$ & $10.75 \pm 3.67$ & $-1.35^{\mathrm{a}}$ \\
T1 & 10 & $8.90 \pm 3.71$ & $10.45 \pm 3.08$ & 0.025 \\
\hline
\end{tabular}

T0 = control (without prill fat addition); $\mathrm{T} 1=$ addition of $2 \%$ prill fat

${ }^{\mathrm{a}, \mathrm{b}}$ Different superscripts between delta at the same column show significant differences $(p<0.05)$

Table 8: Milk component of dairy cows in KUNAK, Cibungbulang $(\mathrm{n}=20)$

\begin{tabular}{|c|c|c|c|c|c|c|c|}
\hline \multirow[b]{2}{*}{ Milk component (\%) } & \multicolumn{2}{|l|}{ T0 } & \multirow[b]{2}{*}{ Delta $(\Delta)$} & \multicolumn{2}{|l|}{$\mathrm{T} 1$} & \multirow[b]{2}{*}{ Delta $(\Delta)$} & \multirow[b]{2}{*}{ T-Test } \\
\hline & Before & After & & Before & After & & \\
\hline$\overline{\text { Fat }}$ & $3.09 \pm 2.13$ & $3.16 \pm 2.07$ & $0.07^{\mathrm{a}}$ & $2.67 \pm 1.15$ & $3.51 \pm 1.26$ & $0.84^{\mathrm{b}}$ & 0.042 \\
\hline Lactose & $4.21 \pm 0.33$ & $4.22 \pm 0.32$ & 0.01 & $4.19 \pm 0.27$ & $4.15 \pm 0.28$ & -0.04 & 0.074 \\
\hline Protein & $2.81 \pm 0.22$ & $2.82 \pm 0.18$ & 0.01 & $2.79 \pm 0.18$ & $2.77 \pm 0.18$ & -0.02 & 0.117 \\
\hline Total solid & $10.75 \pm 1.77$ & $10.84 \pm 1.89$ & 0.09 & $10.45 \pm 1.36$ & $11.02 \pm 1.02$ & 0.57 & 0.194 \\
\hline
\end{tabular}

$\mathrm{T} 0=$ control (without prill fat addition); $\mathrm{T} 1$ = addition of $2 \%$ prill fat

${ }^{\mathrm{a}, \mathrm{b}}$ Different superscripts between delta on the same row show significant differences $(p<0.05)$

Table 9: Milk fatty acid profile of dairy cows in KUNAK, Cibungbulang $(\mathrm{n}=20)$

Fatty acid profile (\% milk fat) Treatments

Saturated Fatty Acid (SFA)

T0

T1

T-Test

Caproic acid (C6:0)

Caprylic acid (C8:0)

$1.54 \pm 0.51^{\mathrm{a}}$

$0.72 \pm 0.22$

$0.88 \pm 0.21$

Capric acid (C10:0)

$1.95 \pm 0.45$

Lauric acid (C12:0)
Myristic acid (C14:0)

$3.33 \pm 1.13$

Pentadecanoic acid (C15:0)

$0.42 \pm 0.09$

$17.35 \pm 4.66$

$0.60 \pm 0.36$

Heptadecanoic acid (C17:0)

$19.30 \pm 0.15$

Octadecanoic acid (C:18)

$0.21 \pm 0.11$

cis-10 pentadecanoic acid (C15:0, cis-10) $\quad 1.16 \pm 0.59$

$1.99 \pm 1.29^{\mathrm{a}}$

$0.64 \pm 0.23$

$1.02 \pm 0.12$

$0.04 \pm 0.50$

$36.49 \pm 0.21$

$1.61 \pm 0.34^{\mathrm{b}}$

0.030

Mono Unsaturated Fatty Acid (MUFA)

Myristoleic acid (C14:1)

cis-10 heptadecanoic (C17:1, cis-10)

cis-9 oleic acid metil ester (C18:1, cis-9)

Poly Unsaturated Fatty Acid (PUFA)

Linolenic acid (C18:3)

$3.40 \pm 0.29$

$6.15 \pm 2.62$

$1.32 \pm 0.42^{\mathrm{a}}$

Conjugated Linoleic Acid (CLA)

Saturated fatty acid (SFA)

Mono unsaturated fatty acid (MUFA)

$47.46 \pm 3.05$

$40.18 \pm 3.42$

$0.79 \pm 0.16$

0.074

$1.06 \pm 0.09$

0.074
0.166

$2.01 \pm 0.61$

0.324

$4.18 \pm 0.92$

0.074

$0.46 \pm 0.11$

$18.38 \pm 3.86 \quad 0.109$

$0.72 \pm 0.32 \quad 0.443$

$19.90 \pm 0.31 \quad 0.337$

$0.21 \pm 0.07 \quad 0.595$

$0.91 \pm 0.47 \quad 0.337$

Poly unsaturated fatty acid (PUFA)

Short chain fatty acids (C4-C12)

$10.87 \pm 1.46$

$5.09 \pm 0.63$

$26.51 \pm 2.49$
$66.91 \pm 3.14$

$1.19 \pm 0.69^{\mathrm{b}}$

0.018

$0.73 \pm 0.17$

0.193

$0.90 \pm 0.28$

1.000

$0.13 \pm 0.25$

0.708

$33.35 \pm 0.18-0.984$

Medium chain fatty acids (C14-C16:1)

$3.23 \pm 0.86$

0.595

$7.03 \pm 2.02$

0.178

$1.55 \pm 0.58^{\mathrm{b}}$

$50.23 \pm 3.52$

0.043

$36.30 \pm 3.74$

$11.81 \pm 1.50 \quad 0.346$

$5.46 \pm 0.53 \quad 0.351$

$27.48 \pm 2.41-0.490$

Hypocholesterolemic/

Hypercholesterolemic $(\mathrm{HH}) \quad 0.46 \pm 0.03$

$65.40 \pm 3.89$

0.490

Atherogenicity Index (AI)

$2.41 \pm 0.52$

$0.46 \pm 0.08$

0.996

$\mathrm{T} 0=$ control (without prill fat addition); $\mathrm{T} 1=$ addition of $2 \%$ prill fat

$2.82 \pm 0.42$

0.217

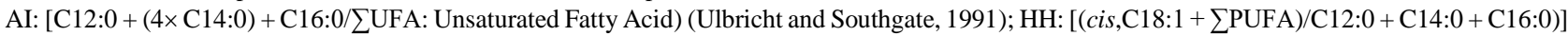
(Santos-Silva et al., 2002)

${ }^{\mathrm{a}, \mathrm{b}}$ Different superscripts on the same row show significant differences $(p<0.05)$ 


\section{Discussion}

\section{Characteristics of Ruminal Fermentation and Rumen Microbial Activity (In Vitro Trial)}

The in vitro fermentation process can be optimal if the rumen fluid is in a $\mathrm{pH}$ condition that is suitable with the rumen microbial environment. The $\mathrm{pH}$ value in all treatments was in the range of 6.8 which indicates that this value was in the normal conditions to support fermentation activity in the rumen (McDonald et al., 2011). The protozoa population from the study decreased along with the increase in the percentage of prill fat addition. This condition can be predicted that protozoa had no lipolytic activity as bacteria in entangled conditions with fat particles, so that the metabolic activity of protozoa tend to decrease when higher prill fat levels are added in dairy ration. The result was consistent with Behan et al. (2019) which reported that the decrease of total ruminal protozoa population in ruminant is caused by the addition of prill fat in the ration.

The rumen bacteria population decreased along the increasing level of prill fat added to the ration that is in the normal population range according to McDonald et al. (2011), was 9-10 log cfu/mL. These results were consistent with Pantoja et al. (1994) that fat in the rumen was associated with ration particles with a physical surface covering and inhibiting rumen microbial metabolism.

Similar with the total rumen bacteria count, the effect of prill fat addition in the dairy ration had a significant effect $(p<0.05)$ on the cellulolytic bacteria population. This can be caused by the surface covering of prill fat, so that cellulolytic bacteria unable to digest fiber when the ration has a high-fat content. Cellulolytic bacteria are bacteria that break down cellulose into glucose which is used for the synthesis of macromolecules and microbial cells (Samsu et al., 2010). Cellulolytic bacteria had a slow growth than amylolytic bacteria (Samsu et al., 2010) which caused a decrease in the ability of bacteria to maintain their biomass in digesting rations with high-fat content.

The use of prill fat in different levels did not significantly affect the amylolytic and proteolytic bacteria population. It may be due to the ration that had an equal protein content in each treatment which did not affect the biomass of proteolytic bacteria. Amylolytic bacteria had a faster growth phase to support rumen fermentation than cellulolytic bacteria which can be reflected in a balanced population after the addition level of prill fat.

Proteolytic bacteria are bacteria that break down proteins, amino acids and other peptides into ammonia (Orskov, 1982) and produce intermediate compounds and other end products that vary widely. According to Czerkawski (2013), the type of feed that consumed by livestock will affect the bacterial population and the proportion of each microbial species.
The average ammonia concentration of the rumen fluid with prill fat supplementation in this study ranged from 8.56-10.14 mM. McDonald et al. (1995) stated that ammonia $\left(\mathrm{NH}_{3}\right) \mathrm{Nconcentration}$ in the rumen was around 5-17.65 mM. In this study, prill fat supplementation had no effect on ammonia $\left(\mathrm{NH}_{3}\right)$ Nconcentrations. This was due to the absence of protein content in prill fat. This study was in accordance with Riestanti et al., (2020) that prill fat supplementation did not affect ammonia $\left(\mathrm{NH}_{3}\right)$ Nconcentrations. Study of Montgomery et al. (2008) reported that lipid supplementation did not affect $\mathrm{N}$ metabolism in the rumen. Furthermore, the activity of proteolytic bacteria is not affected by the addition of prill fat in term of the non-existence of protein content in prill fat.

VFA roles as an energy source for livestock and a carbon source for microbial protein synthesis (Rodríguez et al., 2007). The average value of total VFA concentration with prill fat supplementation ranged from 107.78-127.14 mM. This value was still in the range of normal VFA concentrations that found in ruminants. According to McDonald et al. (1995), VFA concentrations that support microbial growth ranged from $80-160 \mathrm{mM}$. Addition of $6 \%$ prill fat $(\mathrm{P} 4)$ treatment resulted in the highest level of total VFA concentration. This condition can be predicted that the addition of fat will increase the total VFA due to the enhancement of feed degradation processes by rumen microorganisms. Jenkins et al. (2008) stated that lipids which enter the rumen will undergo lipolysis which causes fat to be degraded into fatty acids and glycerol, then glycerol will be converted into VFA.

Recent study conducted by Riestanti et al., (2020) reported that the concentration of total Volatile Fatty Acids (VFA) was influenced by the level of prill fat addition at different levels of palmitic acid. Prill fat that contained 96\% Palmitic Acid (PA) produced the highest VFA value compared to the control and the other treatments (76 and $86 \%$ PA content), but the total VFAconcentration of all treatments was still in the normal range of VFA concentrations in the rumen, so the prill fat addition at the level of $2 \%$ was not interfering the rumen fermentation activity.

Research by Naik et al. (2010) showed that the addition of bypass fat in the form of Calcium salts of Long Chain Fatty Acids (Ca-LCFA) $300 \mathrm{~g} / \mathrm{day}$ with a ratio roughage: Concentrate 65:35 using in vivo did not affect the ammonia concentration in the rumen. Chalupa et al. (1986) also reported that the addition of 5-15\% bypass fat had no effect on the rumen fermentation characteristics of dairy cows. Naik et al. (2009) reported that the addition of protected fat in the form of Ca-LCFA did not affect Dry Matter Digestibility (DMD), ammonia concentration and $\mathrm{pH}$. The addition of protected fat in the ration showed an effect on the total VFA concentration due to an increase in energy by fat. 


\section{Nutrient Digestibility the Dairy Ration Supplemented of Prill Fat}

The dairy ration digestibility produced in this study was in the normal digestibility according to Lestari and Abdullah (2015), it was above 60\%, although there was a depression in the dry matter digestibility and organic matter digestibility along with the increasing level of prill fat addition. This condition caused by an interfere of palm oil prill fat with the microbial activity of the rumen due to the nature of the fat that can surrounded the feed particles. This result can be seen in the cellulolytic bacterial population (Table 4) which decreased significantly along with the enhancement of prill fat addition in the ration.

The highest NDF digestibility was in control treatment with $59.03 \%$ and the digestibility decreased along with the increase in the level of prill fat addition in the ration. This can be caused by a decrease of rumen bacteria activity, especially the cellulolytic bacterial population, which has decreased significantly to the addition of prill fat levels. It can also be predicted due to the physically closure of the feed particles by fat, so that the bacteria cannot maintain the ecosystem conditions in the rumen. Adesogan et al. (2019) stated that lignocellulose bonds also become a limitation in the use of feed ingredients in dairy rations because they could reduce the digestibility level in the nutritional value of the feed.

In addition, there were drawbacks of the in vitro method of Tilley and Terry (1963), which was unable to measure the post-rumen digestive system. Protected fat will pass through the rumen without changing the postrumen digestive system and resulting the absorption of fatty acids in the jejunum area of the small intestine (Lock et al., 2006). Measurement of post-rumen digestion of fat can be carried out using the in vivo method or the addition of lipase enzymes separately in the in vitro method. Therefore, for further research, the addition of lipase enzyme should be done to measure post-rumen fat digestion.

\section{Dairy Cow Performance in KUNAK, Dairy Farm, Cibungbulang (In Vivo Trial)}

\section{Dry Matter Intake}

Dry matter intake is the amount of feed that can be consumed by cattle for cattle production. Dry matter intake in this study was lower than the study by Despal et al. (2013) which was $23 \mathrm{~kg}$ DM. In this study, the addition of prill fat to the ration had no effect on the amount of Dry Matter (DM) intake. This can be predicted that prill fat isa hydrogenated fatty acid. Prill fat contains fewer double bonds (6\%), so their addition did not affect feed consumption. Prill fat contains high levels of saturated fatty acids (palmitic) so that it does not affect gastrointestinal motility. The degree of saturation of a fatty acid that reaches the small intestine in dairy cattle, will cause disturbances to gastrointestinal motility and will cause a decrease in dry matter intake (Drackley et al., 1992). Relling and Reynolds (2007) reported that the decrease in dry matter consumption is caused by the fat supplemented into the ration, which will cause an association with an increase in the concentration of peptide-1 in plasma, i.e., glucagon (a peptide hormone in the small intestine with a hypophagic effect.

\section{Dairy Cow's Milk Yield}

The enhancement of milk production after prill fat supplementation can be caused by an increase in de novo lipogenesis and pre-formed uptake of fatty acids (Mathews et al., 2016).

The increase in milk production can also be caused by the substitution of starch by protected fat so that there was a positive energy balance in dairy cattle, thereby changing the metabolism in the mammary glands (Wina and Susana., 2013). The energy that used by the dairy cow is obtained from their rations and the mobilization of fat in their bodies which can be maintained for production.

The depression of milk yield in Control (T0) was a normal condition for dairy cows, where the normal persistence in dairy cows is $89-92 \%$ which indicates that milk production has decreased by $8 \%$ every 30 days (Lowry, 1990). The persistence of milk production in the control treatment was $89.8 \%$. This result showed that there was a decrease of $11 \%$ every 30 days. The enhancement of milk yield in Treatment (T1) with a persistence value of $110.6 \%$ after the peak was not normal, this can be caused by a nutrient improvements or recovery from disease.

\section{Dairy Cow's Milk Components}

Milk fat is one of the most important components in milk and the addition of prill fat in the ration can enhance the total of milk fat. This can be caused by the precursors for the synthesis of milk fat is fatty acids which derived from the rumen fermentation, mobilization of body fat and feed (Despal et al., 2019). According to Maheswari (2004), milk fat content was influenced by feed because most of the milk components were synthesized in udders from simple substrates.

The enhance of the fatty acids availability in feed will increase the rate of milk fatty acid synthesis which can be done by provide the sufficient of energy. It can be reflected in the enhancement of milk fat levels inlactating dairy cows which are given the prill fat in the ration.

Bypass fat supplementation reported to increase energy consumption and known to have a significanteffect on increasing milk production. Accordingly, many studies have been conducted with the aim of fat as an energy source using prill fat was reported by Kundu et al. (2014), Piantoni et al. (2015), Chamberlain and DePeters (2017), de Souza et al. 
(2017) and Mathews et al. (2016), which stated that there was an increase in milk production and milk fat in dairy cow, but had no effect on body weight gain and dry matter intake of dairy cows.

\section{Dairy Cow's Milk Fatty Acid Profile}

The enhancementof fatty acid content in milk is influenced by the presence of sufficient energy supply for fatty acid synthesis in the udder glands, in addition to milk production. The addition of Saturated Fatty Acids (SFA) to the ration was reported to increase the circulation of NonEsterified Fatty Acid (NEFA) on dairy cattle (Piantoni et al., 2013). The ability of saturated fatty acids to increase NEFA synthesis is due to the high supplementation of palmitic acid (C:16) in the ration (Mathews et al., 2016). Long chain fatty acids $(\mathrm{C}>12)$ are converted to $\mathrm{CoA}$ and the triacylglycerol (TAG) has re-esterification during the absorption process. TAG then broken down into chylomicrons with the support of lipoprotein lipase in the tissues which then contributes to the circulation of NEFA in ruminants and it depends on lipase activity in certain tissues (Bickerton et al., 2007).

Atherogenicity Index (AI) was in the part of milk fatty acid profile which became an important value in functional food. Based on this study, the AI of milk for dairy cows in KUNAK Cibungbulang was in the low AI value according to Sharma et al. (2018) with AI values for normal dairy cows ranging from 1.6 to 3.79 . AI in the control were 2.41 and 2.82 in the $2 \%$ prill fat treatment. Nantapo et al. (2014) examined the fatty acid composition during lactation at different periods and found that the lowest AI was resulted a value range from 4.08 to 5.13. The ratio of Hypocholesterolemic/Hypercholesterolemic $(\mathrm{HH})$ is more accurate in reflecting the effect of fatty acid composition on Cardiovascular Disease (CVD) than the PUFA or SFA ratio. The value of HH ratio in dairy cow's milk according to Salles et al. (2019) ranging from 0.406 to 0.573 . In this study, the value of $\mathrm{HH}$ ratio in dairy cow's milk in KUNAK Cibungbulang was 0.46 in control and treatment. These results indicate that $2 \%$ prill fat supplementation into the ration did not have a negative effect on the AI index and $\mathrm{HH}$ ratio of dairy cow.

\section{Conclusion}

Prill fat supplementation of $86 \%$ palmitic fatty acid at $2 \%$ level in dairy cow's ration did not interfere on rumen ferment ability and in vitro digestibility. Supplementation of $2 \%$ prill fat on in vivo enhanced the milk yield, milk persistence and improve milk fat profile as indicated by the alteration of PUFA and CLA.

\section{Acknowledgement}

This research was funded by Indonesian Ministry of Education within the Scheme of National post graduate
Research Competitive year of 2020 with contract No. 16/E1/KPT/2020 and No. 27/E1/KPT/2020 (3) and agreement contract No. 1/E1/KP.PTNBH/2020 and 1/AMD/E1/KP.PTNBH/2020.

\section{Author's Contributions}

Lolita Udin Riestanti: Participated in all experiments, analyzed, interpreted the data and wrote the manuscript.

Despal: Designed, supervised the laboratory and in vivo work, interpreted the data and proofread the manuscript.

Yuli Retnani: Designed and supervised the experiment work and wrote the manuscript.

\section{Ethics}

This article is original and contains unpublished material. The corresponding author confirms that all of the other authors have read and approved the manuscript and no ethical issues involved.

\section{References}

Adesogan, A. T., Arriola, K. G., Jiang, Y., Oyebade, A., Paula, E. M., Pech-Cervantes, A. A., ... \& Vyas, D. (2019). Symposium review: Technologies for improving fiber utilization. Journal of Dairy Science, 102(6), 5726-5755. https://doi.org/10.3168/jds.2018-15334

Behan, A. A., Loh, T. C., Fakurazi, S., Kaka, U., Kaka, A., \& Samsudin, A. A. (2019). Effects of supplementation of rumen protected fats on rumen ecology and digestibility of nutrients in sheep. Animals, 9(7), 400. https://doi.org/10.3390/ani9070400

Bickerton, A. S., Roberts, R., Fielding, B. A., Hodson, L., Blaak, E. E., Wagenmakers, A. J., ... \& Frayn, K. N. (2007). Preferential uptake of dietary fatty acids in adipose tissue and muscle in the postprandial period. Diabetes, 56(1), 168-176. https://doi.org/10.2337/db06-0822

BSN. (2011). Definisi Susu Segar (SNI 01-3141.1:2011). Dewan Standarisasi Nasional, Jakarta, Indonesia. Badan Standarisasi Nasional. (full article in Indonesian language).

http://blog.ub.ac.id/cdrhprimasanti90/files/2012/05/2770 5_SNI-3141.1-2011-Susu-Segar-Bag.1-Sapi.pdf

Chalupa, W., Vecchiarelli, B., Elser, A. E., Kronfeld, D. S., Sklan, D., \& Palmquist, D. L. (1986). Ruminal fermentation in vivo as influenced by long-chain fatty acids. Journal of Dairy Science, 69(5), 1293-1301. https://doi.org/10.3168/jds.S0022-0302(86)80535-5

Chamberlain, M. B., \& DePeters, E. J. (2017). Impacts of feeding lipid supplements high in palmitic acid or stearic acid on performance of lactating dairy cows. Journal of Applied Animal Research, 45(1), 126-135. https://doi.org/10.1080/09712119.2015.1124327 
Conway, E. J. (1962). Microdiffusion Analysis and Volumetric Error, Crosby Lockwood \& Son, London. Nitrogen and Water Excretion of Wallabies, 367.

Czerkawski, J. W. (2013). An introduction to rumen studies. Netherlands. Elsevier, Pergamon Pr. https://doi.org/10.1016/C2009-0-00551-0

de Souza, J., Garver, J. L., Preseault, C. L., \& Lock, A. L. (2017). Effects of prill size of a palmitic acidenriched fat supplement on the yield of milk and milk components and nutrient digestibility of dairy cows. Journal of Dairy Science, 100(1), 379-384. https://doi.org/10.3168/jds.2016-11610

Despal, I. G. P., Toharmat, T., \& Amirroennas, D. E. (2019). Pemberian Pakan Sapi Perah. PT Penerbit IPB Press.ISBN-10: 602440705X.

Despal, L. A., Destianingsih, Y., Malyadi, Z., Hartono, H., \& Abdullah, L. (2013, September). Nutrients intake and their relation to milk production and qualities under traditional and small scale Indonesian dairy farms enterprises. In Proceeding 3rd AINI International Seminar (pp. 24-25). https://studylib.net/doc/8929099/proceeding--departemen-intp---bogor-agricultural-university

Drackley, J. K., Klusmeyer, T. H., Trusk, A. M., \& Clark, J. H. (1992). Infusion of long-chain fatty acids varying in saturation and chain length into the abomasum of lactating dairy cows. Journal of Dairy Science, 75(6), 1517-1526. https://doi.org/10.3168/jds.S0022-0302(92)77908-9

Firkins, J. L., Yu, Z., \& Morrison, M. (2007). Ruminal nitrogen metabolism: perspectives for integration of microbiology and nutrition for dairy. Journal of Dairy Science, 90, E1-E16. https://doi.org/10.3168/jds.2006-518

Hasanah, U., Permana, I. G., \& Despal. (2017). Introduction of complete ration silage to substitute the conventional ration at traditional dairy farms in Lembang. Pakistan Journal of Nutrition., 16(8), 577587.https://doi.org/10.3923/pjn.2017.577.587

Jenkins, T. C., Wallace, R. J., Moate, P. J., \& Mosley, E. E. (2008). Board-invited review: Recent advances in biohydrogenation of unsaturated fatty acids within the rumen microbial ecosystem. Journal of Animal Science, 86(2), 397-412. https://doi.org/10.2527/jas.2007-0588

Karcagi, R. G., Gaál, T., Ribiczey, P., Huszenicza, G., \& Husvéth, F. (2010). Milk production, peripartal liver triglyceride concentration and plasma metabolites of dairy cows fed diets supplemented with calcium soaps or hydrogenated triglycerides of palm oil. The Journal of Dairy Research, 77(2), 151. https://doi.org/10.1017/S0022029909990604
Kundu, M. S., De, A. K., Jeyakumar, S., Sunder, J., Kundu, A., \& Sujatha, T. (2014). Effect of prill fat supplementation on hormones, milk production and energy metabolites during mid lactation in crossbred cows. Veterinary World, 7(6). https://doi.org/10.14202/vetworld.2014.384-388

Lestari, D. A., \& Abdullah, L. (2015). Comparative study of milk production and feed efficiency based on farmers best practices and National Research Council. Media Peternakan, 38(2), 110-117. https://doi.org/10.5398/medpet.2015.38.2.110

Lock, A. L., Harvatine, K. J., Drackley, J. K., \& Bauman, D. E. (2006). Concepts in fat and fatty acid digestion in ruminants. In Proc. Intermountain Nutr. Conf (pp. 85-100).

https://www.researchgate.net/publication/26649983 0_Concepts_of_fat_and_fatty_acid_digestion_in_ru minants

Lowry, D. (1990). Persistency of Milk Production. Alberta Agriculture, Alberta (CAN). http://agromedia.ca/ADM_Articles/content/DHI_lac tcrv.pdf

Maheswari, R. R. A. (2004). Penanganan dan Pengolahan Hasil Ternak Perah. Institut Pertanian Bogor Press, Bogor. (full article in Indonesian language).

Mathews, A. T., Rico, J. E., Sprenkle, N. T., Lock, A. L., \& McFadden, J. W. (2016). Increasing palmitic acid intake enhances milk production and prevents glucosestimulated fatty acid disappearance without modifying systemic glucose tolerance in mid-lactation dairy cows. Journal of Dairy Science, 99(11), 8802-8816. https://doi.org/10.3168/jds.2016-11295

McDonald, P., Edward, R. A., Greenhalgh, J. F. D., Morgan, C. A., Sinclair, L. A., \& Wilkinson, R. G. (2011). Animal Nutrition $7^{\text {th }}$ Ed. Pierson Education Ltd, Harlow. http://gohardanehco.com/wpcontent/uploads/2014/02/Animal-Nutrition.pdf

McDonald, P., Edwards, R. A., Greenhalgh, J. F. D., \& Morgan, C. A. (1995). Animal Nutrition 5thEdition. Pearson Education LTD. Edinburgghgate McGrawhill companies. Habow United Kingdom, printed in Malaysia, 880, 561-562.

Montgomery, S. P., Drouillard, J. S., Nagaraja, T. G., Titgemeyer, E. C., \& Sindt, J. J. (2008). Effects of supplemental fat source on nutrient digestion and ruminal fermentation in steers. Journal of animal science, 86(3), 640-650. https://doi.org/10.2527/jas.2006-812

Naik, P. K. (2013). Bypass fat in dairy ration-a review. Anim Nutr Feed Techol, 13, 147-63. https://www.researchgate.net/publication/25872215 0_Bypass_fat_in_dairy_ration-a_review 
Naik, P. K., Saijpaul, S., \& Kaur, K. (2010). Effect of supplementation of indigenously prepared rumen protected fat on rumen fermentation in buffaloes. Indian Journal of Animal Sciences, 80(9), 902. https://www.researchgate.net/publication/29567963 1_Effect_of_supplementation_of_indigenously_prep ared_rumen_protected_fat_on_rumen_fermentation _in_buffaloes

Naik, P. K., Saijpaul, S., \& Rani, N. (2009). Effect of ruminally protected fat on in vitro fermentation and apparent nutrient digestibility in buffaloes (Bubalus bubalis). Animal Feed Science and Technology, 153(1-2), 68-76.

http://dx.doi.org/10.1016/j.anifeedsci.2009.06.008

Nantapo, C., Muchenje, V., \& Hugo, A. (2014). Atherogenicity indeks and health-related fatty acids in different stages of lactation from Friesian, Jersey and Friesian $\mathrm{x}$ Jersey cross cow milk under a pasturebased dairy system. Food Chem.,146, 127-133. https://doi.org/10.1016/j.foodchem.2013.09.009

NRC. (2001). Nutrient Requirements of Dairy Cattle $7^{\text {th }}$ revised ed. National Academy Press, Washington DC. National Research Council.

Ogimoto, K., \& Imai, S. (1981). Atlas of rumen microbiology. Japan Scientific Societies Press. https://www.cabdirect.org/cabdirect/abstract/1982 1429229

Orskov, E. R. (1982). Protein nutrition in ruminants. Academic Press Inc.(London) Ltd. https://www.cabdirect.org/cabdirect/abstract/198214 39163

Pantoja, J., Firkins, J. L., Eastridge, M. L., \& Hull, B. L. (1994). Effects of fat saturation and source of fiber on site of nutrient digestion and milk production by lactating dairy cows. Journal of Dairy Science, 77(8), 2341-2356. https://doi.org/10.3168/jds.S00220302(94)77177-0

Piantoni, P., Lock, A. L., \& Allen, M. S. (2013). Palmitic acid increased yields of milk and milk fat and nutrient digestibility across production level of lactating cows. Journal of Dairy Science, 96(11), 7143-7154. https://doi.org/10.3168/jds.2013-6680

Piantoni, P., Lock, A. L., \& Allen, M. S. (2015). Saturated fat supplementation interacts with dietary forage neutral detergent fiber content during the immediate postpartum and carryover periods in Holstein cows: Production responses and digestibility of nutrients. Journal of Dairy Science, 98(5), 3309-3322. https://doi.org/10.3168/jds.2014-8798

Relling, A. E., \& Reynolds, C. K. (2007). Feeding rumeninert fats differing in their degree of saturation decreases intake and increases plasma concentrations of gut peptides in lactating dairy cows. Journal of Dairy Science, 90(3), 1506-1515. https://doi.org/10.3168/jds.S0022-0302(07)71636-3
Retnani, Y., Saenab, A., Taryati. (2014). Vegetable waste as wafer feed for increasing productivity of sheep. Asian Journal of Animal Sciences, 8, 24-28. https://doi.org/10.3923/ajas.2014.24.28

Riestanti, L. U.,Retnani, Y., \& Despal. (2020). Fermentability and Digestibility Responses of Prill Fat Supplementation in Dairy Ration. In IOP Conference Series: Earth and Environmental Science (Vol. 411, No. 1, p. 012037). IOP Publishing.

https://iopscience.iop.org/article/10.1088/17551315/411/1/012037

Rodríguez, R., Sosa, A., \& Rodríguez, Y. (2007). Microbial protein synthesis in rumen and its importance to ruminants. Cuban Journal of Agricultural Science, 41(4), 287-294. https://www.researchgate.net/publication/27690167 2_Microbial_protein_synthesis_in_rumen_and_its_i mportance_to_ruminants

Sajimin, \& Purwantari, N. D. (2019). Evaluation performance of three Pennisetum genus grown on pines forest in Lembang, West Java. Pastura., 8(2), 97-100. https://doi.org/10.24843/Pastura.2019.v08.i02.p07

Salles, M. S., D’Abreu, L. F., Júnior, L. C. R., César, M. C., Guimarães, J. G., Segura, J. G., ... \& Netto, A. S. (2019). Inclusion of sunflower oil in the bovine diet improves milk nutritional profile. Nutrients, 11(2), 481. https://doi.org/10.3390/nu11020481

Samsu, B. A., Nafis, R. M., Abd, H. L. S., Najib, A. M., Suraini, A. A., Abdul, R. N. A., ... \& Yoshihito, S. (2010). Isolation and characterization of thermophilic cellulase-producing bacteria from empty fruit bunches-palm oil mill effluent compost. American Journal of Applied Sciences, 7(1), 56-62. https://doi.org/10.3844/ajassp.2010.56.62

Santos, K. M., Watanabe, P. H., Freitas, E. R., Nepomuceno, R. C., Oliveira, P. J., Lima, V. M., ... \& Carvalho, L. E. (2017). Beef tallow and emulsifier in growing-finishing pig diets. Anais da Academia Brasileira de Ciências, (AHEAD), 0-0. https://doi.org/10.1590/0001-3765201720160500

Santos-Silva, J., Bessa, R. J. B., \& Santos-Silva, F. J. L. P. S. (2002). Effect of genotype, feeding system and slaughter weight on the quality of light lambs: II. Fatty acid composition of meat. Livestock Production Science, 77(2-3), 187-194. https://doi.org/10.1016/s0301-6226(02)00059-3

Sharma, R., Ahlawat, S., Aggarwal, R. A. K., Dua, A., Sharma, V., \& Tantia, M. S. (2018). Comparative milk metabolite profiling for exploring superiority of indigenous Indian cow milk over exotic and crossbred counterparts. Journal of Food Science and Technology, 55(10), 4232-4243. https://doi.org/10.1007/s13197018-3360-2 
Somagond, Y. M., Singh, S. V., Deshpande, A., Sheoran, P., Chahal, V. P. (2020). Physiological responses, energy metabolites and prolactin levels of buffaloes supplemented with dietary astaxanthin, prill fat and their combination during heat stress. Biological Rhythm Research, 90(1), 55-60. https://dx.doi.org/10.1080/09291016.2019.1658426

Sutarno, S., \& Setyawan, A. D. (2016). The diversity of local cattle in Indonesia and the efforts to develop superior indigenous cattle breeds. Biodiversitas Journal of Biological Diversity, 17(1). https://doi.org/10.13057/biodiv/d170139

Tilley, J. M. A., \& Terry, R. A. (1963). A two-stage technique for the in vitro digestion of forage crops. Grass and Forage Science, 18(2), 104-111. http://dx.doi.org/10.1111/j.13652494.1963.tb00335.x

Ulbricht, T. L. V., \& Southgate, D. A. T. (1991). Coronary heart disease: seven dietary factors. The Lancet, 338(8773), 985-992. https://doi.org/10.1016/01406736(91)91846-M
Van Soest, P. V., Robertson, J. B., \& Lewis, B. A. (1991). Methods for dietary fiber, neutral detergent fiber and nonstarch polysaccharides in relation to animal nutrition. Journal of dairy science, 74(10), 3583-3597. https://doi.org/10.3168/jds.S0022-0302(91)78551-2

Wardeh, M. F. (1981). Models for estimating energy and protein utilization for feeds, dissertation, Logan, Utah State University. https://digitalcommons.usu.edu/etd/4556/

Wina, E., \& Susana, I. W. R. (2013). Benefit of Protected Fat for Improving Production and Reproduction of Ruminant. WARTAZOA. Indonesian Bulletin of Animal and Veterinary Sciences, 23(4). http://medpub.litbang.pertanian.go.id/index.php/war tazoa/article/view/1008

Zahera, R., \& Permana, I. G. (2015). Utilization of mungbean's greenhouse fodder and silage in the ration for lactating dairy cows. Media Peternakan, 38(2), 123-131.

https://doi.org/10.5398/medpet.2015.38.2.123 